and hear his explanation." Surely no such arrangement will satisfy "all the scientific men in the world." We contend that as Mr. Casella has publicly claimed the invention as his own, it ought to be decided witn equal publicity whether he has done anything more than copy our instrument.

We again give the description of our thermometer (not in our own words, for we might be accused of shaping them to suit our purpose) but in the words of the late Admiral Fitzroy as they appear in the frst number of Meteorological Papers, page 55, published July 5, I857, in referring to the erroneous readings of all thermometers consequeat on their delicate bulbs being compressed by the great pressure of the ocean, Admiral Fitzroy says :-

"With a view to obviate this failing, Messrs. Negretti and Zambra undertook to malke a case for the weak bulbs which should transmit temperature but resist pressure. Accordingly, a tube of thick glass is sealed outside the delicate bulb between which and the casing is a space all round which is nearly fillect with mercury. The small space not so filled is a vacuum into which the mercury can be expanded, or forced by heat or mechanical compression, without doing injury to, or even compressing the inner or rnuch more delicate bulb," \&c. \&c.

Mr. Casella "did not wish to take up your valuable space to describe his thermometer." Well, it matters not; the late Admiral Fitzroy has done it for him. He described it sixteen years ago; and if the reader will take every syllable of the extract above quoted, and substitute the word "alcohol" for " miercury" (which colourable change was effected by Mr. Casella, to the detriment of the instrument), they will have a correct description of Mr. Casella's themometer in the most minute details.

HEy. NEGRETIT AND ZAMBRA.

\section{Rain-gauge at Sea}

I $13 \mathrm{EG}$ to send you a copy of a letter I received lately from Capt. Goodenough, of the Royal Navy, respecting the use of my rain-gange at sea. (See NATURE, vol. vii. p. 202.) Nov. 8

W. J. BLACK

"H.M.S. Perr, Iat. $6^{\circ}$ S., long. $22 \mathrm{~W}$.

"Dear Sir,--I shonld have taken an earlie" opportunity of writing to you about the instrument which you were so good as to design for use on board ship, but have not had the good fortune to fall in with any rain up to the present time with which I could at all events in some measure test and chronicle the rain-gaugre. It is odd that in a journey of twenty clays I have had only ' $\mathrm{T}$ in. of rain, and that although $I$ am at this moment in a district in which an average of seven hours' rain wsually falls at this time of the year. On that one occasion $07 \mathrm{in}$. did fall and was duly caught in your instrument as well as in another mounted on cimbals, the measurements being exactly alike in each. I much prefer the mounting of your instrument, and will report to you as to the amomt of weight it requires afrer some experimenting with it. The usually most steady instrument is one which is heavy, and whose centre of gravity is very near its centre of oscillation. I do not think it would be well to increase the size of the instrument, as it would become inconvenient to place, except for the use of a man who wisles to devote himself very much to that orcler of observation. Our poop is so high here that I do rot anticipate any mixture of sca-spray in the galage, but if it were so your table would be sufficient to clear it, supposing we had Carpenter's Hydrometer to test with, as we might not expect enough water to float an ordinary one.

"I remain, yours very truly,

"James E. Goodenough

"Captain R.N. Command H.M.S. Pearl, proceeding vita the Cape to Australasia."

\section{Glaciers}

In a letter printed in your number for Oct. 16 (vol. viii. p. 506), Mr. J. H. Roblirs states that he believes that glaciers existed at or near the sea-level in centrai Hindustan in the glacial period. Glaciers undoubtedly existed in tine Himalyas at a much lower elevation than at present; there are traces of their action in Sikkim in valleys, the bottoms of which are now only 4,000 ft. above the sea, and in the nortl-western Himalayas, Mr.
Medlicott, I think, considers that in sorne valleys, glaciers descended to within $x, 000 \mathrm{ft}$. of the sea-level, but $I$ have never heard of any marks of old glacial action in the Indian peninsula south of the Himalayas. There are no mountains in central Hindostan exceeding about 4,00o ft. in height, and a careful examination of the portions of the Nilgiri mountains in Southern India, which rise above 8,000 ft., has not afforded any proof of the former presence of ice. It is very probable that Mr. Rölurs possesse: information upon this subject with which $I$ am unac. quainted, and it is without the least wish to express a doubt of the aecuracy of his information, that I ask for any evidence he can produce in favour of his assertion, as the subject is one in which $I$ am greatly interested.

\section{W. T. BLANFORD}

\section{JOHANN NEPOMUK CZERMAK}

TOHANN NEPOMUK CZERMAK was born June 17 , 1828, in Prague. His father, Johann Conrad Czermak, was a medical practitioner of high repute in that city, and his uncle, Joseph Julius Czermak, enjoyed a considerable reputation as Professor of Medicine and Physiology, first at Gratz and afterwards at Vienna. Educated at the high school of his native town, Joha nn Czermak entered upon the study of medicine at the University of Vienna in I845. In I847 ke moved to Breslau, where he had the great advantage of living with the distinguished physiologist Purkinje. From Breslau he passed on in I849 to Wurzburg, where in 1850 he received the degree of M.D., publishing on that occasion an inaugural dissertation on "The Microscopical Anatomy of the Teeth," in which he called attention to the larger "interglobular" spaces so often found in the upper part of the dentine. After a visit to England he settled at Prague, where he became assistant to Purlinje, who then held the chair of Physiology in that place. In 1855 he left Prague to take the chir of Zoology at Gratz; but zoology was not his proper province, and he gladly accepted in 1856 the offer of the Professorship of Physiology at Krakau, which however he left in the following year for the like chair in Pesth. In both these universities he established physiological laboratories and gave a decided impulse to physiological research; but the political agitations then rife made life distasterul to him there, and in 1860 he resigned his chair and returned to Prague. Such frequent changes must have interfered greatly with sustained research, but by this time Czermak had made his name known as well by several investigations in experimental physiology and in subjective vision, as especially by his researches on the laryngoscope, his treatise on which "Der Kenlkopfspiegel und seine Verwerthung") embodying the results made known in various papers in 1858 and 1859 , he piablished shortly before his return to Prague.

Here he resided some years, visiting at times En gland, Holland, and France, in order to make the value of the laryngoscope better known to his fellow-workers in science and medicine. There are many in England who retain pleasant memories of these visits.

The ample means brought to him by the gifted lady whom he had the happiness to marry, enabled him to build in Prague and furnish at his own expense a private laboratory for research, in which he not only worked himself, but which he also placed at the disposal of others. Many would have envied, and few would willingly have let slip, such an opportunity for quiet labo:r; but Czermak, conscious of the power he possessed of lucid exposition, delighted in teaching, and felt perhaps the want of the stimulus which pupils afford. Accordingly, when in 1865 he was offered the chair of Physiology in Jena, vacated by the removal of von Bezoid to Wirzbur he at once accepted it. Here he continued until, in 1869 , finding the disease to which he eventually succumbed (and the beginning of which he himself attributed to the irritation caused by the 
controversies which arose out of his laryngoscopic work), was rendering him unfitted for the energetic performance of his professorial duties, he withdrew to Leipzig, where he was made Honorary Professor at the University, and where he continued to reside until his death, on Sept. I6 in the present year.

Carried off while yet in the prime of his life, and the energies of his last few years impaired by an insidious disease, Czermak has perhaps left a mark on the scientific progress of his time incommensurate with his talents or his promise. He will doubtless be best remembered through his laryngoscopic labours. We owe to him the real introduction into medical practice of this valuable instrument. But his other researches, such as those on the action of the vagus, the pulse, the sense of touch, the manége movements resulting from injuries to the brain, those on dyspncea, and others, show remarkable acuteness and clearness of insight.

Two talents he possessed deserve special notice. $\mathrm{He}$ had remarkable aptitude in devising apparatus for observing or for demonstrating physiological phenomena. It was this faculty which made him successful where others had failed in the use of the laryngeal mirror; and

would be difficult to exaggerate the immense help to experimental physiology which has been afforded by the ingenious "holder" which bears his name.

The other faculty, that of popular exposition, less common in his country than in ours, he possessed to a very high degree. And his popular lectures, which were originally delivered at Jena, and which were reviewed in an early number of NATURE, achieved and deserved great popularity.

Perhaps had his love of teaching been less strong, his work as an investigator would have been more sustained and weighty. But while in this country we might with profit often lose a lecturer and gain an investigator, Germany could well afford that one whose powers of rigorous and yet clear and popular demonstration were so exceptionally great, should somewhat slacken in his work as an inquirer. Or perhaps we should not so much say that Czermak slackened in inquiry, as that the consciousness of his power as an expositor, and the delight he consequently took in exposition, drew much of his energy in that direction. In the grounds of his residence at Leipzig he had built and fitted, at his own expense, a large hall, or "spectatorium," as he called it, in which he proposed to deliver lectures on physiology, richly illustrated with experiments. In connection with the hall, the construction of which was admirably adapted in every way for its purpose, he had also erected a private laboratory for research; and on both he had spent much time and labour. They were intended to be a supplement-not a rival-- to the more technical institute of Prof. Ludwig in the same city. The writer will never forget the delight with which Czemak showed this "Erklärungs-Tempel," -....as he was fond of calling it-to Dr. Sharpey and himself in the summer of $187 \mathrm{r}$, and pointed out all its ingenious contrivances, and the entbusiasm with which he looked forward to the lectures which would be delivered, and the work which would be carried on in it. He lived to open it by an inaugural lecture in December 1872 ; but the effects of his fatal disease were already painfully evident; and after a vain struggle during the following summer, Czermak-just as the British Association was gathering for its meeting at Bradford-was taken away from his unfinished work. He was a man of broad culture, cutside his professional attainments. In philosophy especially he was well versed; and his last contribution to scientific literature--a paper in "Pflüger's Archiv," on the mesmerism of animals-was doubtless prompted by his interest in psychological questions. His straightforward, generous, and unostentatious - manner formed a fitting frame for his intellectual attainments.

A widow and children mourn his death. He is also mourned for by many friends in many lands, both by those who had known him long and by those who knew him for a short while only.

M. FosTER

\section{THE ATMOSPHERTC TELEGRAPH}

THE Times of the 15 th inst. contained an article on the Pneumatic Despatch, which has never been used to any extent in this country. From that article we learn the following particulars as to the working of this method of conveyance in London :-

The pneumatic tube extends from the London and North-Western Railway Station at Euston Square to the General Post Office in St. Martin's-le-Grand. The central station is in Holborn, where is also the machinery for effecting the transit of the trains. Here the tube is divided, so that in effect there are two tubes opening into the station, one from Euston to Holborn, and the other from the Post Office. The length of the tube between Holborn and Euston is 3,080 yards, or exactly a mile and three-quarters, a greater length than was originally contemplated, but which was rendered necessary by the avoidance of certain property on the route. The tube is of a flattened horse-shoe section $5 \mathrm{ft}$, wide and $4 \mathrm{ft}$. $6 \mathrm{in}$. high at the centre, having a sectional area of $\mathrm{I} 7$ square feet. The straight portions of the line are formed of a continuous cast-iron tube, the curved lengths being constructed in brickwork, with a facing of cement. The gradients are easy; the two chief are $I$ in 45 and $x$ in 6o, some portions of the line being on the level; the sharpest curve is that near the Holborn station, which is $70 \mathrm{ft}$. radius. The tube between Holborn and the Post Office is 1,658 yards in length, or IO2 yards less than a mile, and is of the same section, and similarly constructed to the first length. Two gradients of $I$ in 15 occur on the Post Office section, but this steep inclination is in no way inimical to the working of the system. The Holborn station is situated at right angles to the line of the tubes, which are therefore turned towards the station into which each opens. All through trains, therefore, have to reverse there, and this is effected in a very simple manner by a self-acting arrangement. A train upon its arrival runs by virtue of its acquired momentum up a short incline, at the summit of which it momentarily stops, and then quickly descends by gravity. In its descent it is turned on to a pair of rails leading to the other tube, into which it enters and through which it continues its journey, the whole process of reversing occupying barely 30 seconds. Trains containing goods for the Holborn station are simply run down from the top of the incline on to a siding.

The waggons, or carriers, as they are termed, weigh $22 \mathrm{cwt}$, are roft. 4 in. in length, and have a transverse contour conforming to that of the tube. They are, however, of a slightly sinaller area than the tube itself, the difference-about an inch all round-being occupied by a fiange of indiarubber, which causes the carrier to fit the tube exactly, and so to form a piston upon which the air acts. The machinery for propelling the carriers consists of a steam engine having a pair of 24 -in. cylinders with $20 \mathrm{in}$. stroke. This engine drives a fan $22 \mathrm{ft}, 6 \mathrm{in}$. in diameter, and the two are geared together in such a manner that one revolution of the former gives two of the latter, or, in technical terms, the engine is geared at 2 to I with the fan. The trains are drawn from Euston and the Post Office by exhaustion, and are propelled to those points by pressure. The working of the fan, however, is not reversed to suit these constantly varying conditions; it works continuously, the alternate action of pressure and exhaustion being governed by valves. The engine takes steam from three Cornish boilers, each $30 \mathrm{ft}$. long and $6 \mathrm{ft} .6 \mathrm{in}$. in diameter, Telegraphic signalling is carried on between the three stations by means of needle instruments. 